\title{
E-ORAL HEALTH AND TELEDENTISTRY IN FINLAND - AN OVERVIEW
}

\author{
Anni Palander DDS ${ }^{1,2,3,4}$, Arto Holopainen MSc(Tech) ${ }^{2}$, Tiina Rantamo DDS, PhD ${ }^{1,3}$ \\ ${ }^{1}$ Kuopio University Hospital Oral Health Teaching Clinic, Kuopio, Finland \\ ${ }^{2}$ City of Kuopio, Strategy and Development, Kuopio, Finland \\ ${ }^{3}$ University of Eastern Finland, Institute of Dentistry, Kuopio, Finland \\ ${ }^{4}$ Finnish Student Health Service, Tampere, Finland
}

\begin{abstract}
Despite universal health coverage and a strong public health system, the oral health profile of Finland falls behind in an international age-matched prevalence of oral diseases. The oral healthcare system is organised and funded mainly by municipalities. Other stakeholders include the Finnish Student Health Service foundation (FSHS), government and private practices, where the Social Insurance Institution of Finland plays a major role in funding. Rise in the treatment need in recent years due to the increasing dentulous ageing population has challenged the healthcare system. Governmental response to the demand is an ongoing social and healthcare reform and increase of oral health professional education since 2004. However, the current and future treatment need is not met only by conventional prevention strategies and physical service provision. Finland has over the years supported a determined policy of building a digital healthcare architecture. This applies also to all fields of oral healthcare: virtual education, digital diagnostics, digital clinical workflow, national electronic patient records, patient-generated data registers, electronic prescriptions, remote consultation, digital service management, as well as research and big data mining. These tools could play an important role in improving national oral health and increasing equity. This is an overview of the above-mentioned fields of e-Oral health and teledentistry in Finland based on current scientific literature, national reports, strategies and legislation.
\end{abstract}

Keywords: telemedicine; dentistry; Finland; remote consultation; data mining; patient generated health data; electronic health records; electronic prescribing

Palander A, et al. JISfTeH 2019;7:e11(1-9).

DOI: https://doi.org/10.29086/JISfTeH.7.e11

Copyright: ${ }^{\circledR}$ The Authors 2019

\section{Introduction}

This paper provides a brief description of the oral health profile, oral healthcare system and oral health workforce education system of Finland and describes the emergence of teledentistry practice in Finland, with a focus on Finland's health, demographic and social conditions. It includes a review of developing fields of e-Oral health and teledentistry with a view of the authors' perspective and the future of eOral health and teledentistry in Finland.

\section{National Burden of Oral Diseases in Finland}

The major burden of oral diseases in Finland, as in most countries, consists of dental caries and periodontal diseases, plus edentulism mostly caused by the progress of these diseases. The state of common oral health indicators in the $21^{\text {st }}$ century is presented in table 1 . In the adult population (age over 30 years) the mean incidence of manifested caries (mean DT) was 0.8 per person, with 1.1 on men and 0.5 on women. ${ }^{1}$ In paediatric patients the corresponding prevalence of manifested caries (mean DT) in 2009 was 0.2 in 5 year olds, 0.3 in 12-year-olds and 0.4 in 17 -year-olds. ${ }^{2}$ In the worldwide age-matched comparison Finland falls to the poorest category in deciduous teeth and second poorest in permanent teeth caries prevalence. ${ }^{3}$ Periodontium was affected by gingivitis on $74 \%$ of the population, on $77 \%$ of men and $70 \%$ of women. Periodontitis i.e. loss of tooth attachment tissue (mild and severe, $\geq 4 \mathrm{~mm}$ probing depth) was present in $64 \%$ of the adult population, in $72 \%$ of men and $57 \%$ of women. ${ }^{1}$ Worldwide the prevalence of severe periodontitis ( $\geq 6 \mathrm{~mm}$ probing depth) in Finland is higher than the worldwide average. ${ }^{4}$ Loss of the full dentition i.e. edentulism in Finland is steadily decreasing. Hence, with a simultaneously ageing population, there is increase in dentulous patients and treatment need. In a 2000 national survey, $15 \%$ of the adult population were edentulous. ${ }^{1}$ In a world-wide age-matched comparison Finland is among the countries with the largest percentage of edentulous population. ${ }^{5}$ One fifth of the population has a mucosal epithelial change of any kind and $8 \%$ of them are potentially neoplastic. ${ }^{1}$ The incidence of oropharyngeal malignancies in 
Table 1. Common oral health indicators in Finland in the $21^{\text {st }}$ century.

\begin{tabular}{|l|c|c|c|}
\hline & Total & Men & Women \\
\hline $\begin{array}{l}\text { Prevalence of detectable caries (DT, } \\
\text { mean number of cavities per person) }\end{array}$ & $\begin{array}{c}\text { Adults } 0.8 \\
\text { Paediatric } 0.3\end{array}$ & 1.1 & 0.5 \\
\hline Prevalence of gingivitis $^{8}$ & $74 \%$ & $77 \%$ & $70 \%$ \\
\hline Prevalence of periodontitis $^{8}$ & $64 \%$ & $72 \%$ & $57 \%$ \\
\hline Incidence of oral cancers $^{13}$ & $680(12,4 / 100 \mathrm{k})$ & $435(16,1 / 100 \mathrm{k})$ & $245(8.8 / 100 \mathrm{k})$ \\
\hline Total tooth loss (edentulism) $^{8}$ & $15 \%$ & $11 \%$ & $17 \%$ \\
\hline Brushing habit twice a day $^{15}$ & $67 \%$ & $53 \%$ & $81 \%$ \\
\hline
\end{tabular}

2016 was 680 cases, corresponding to12.4 cases per population of 100,000 population. ${ }^{6}$ The incidence is low in females and moderate in males compared to the world-wide average. ${ }^{7}$ Many of the previously listed oral diseases strongly reflect the individual's socio-economic status, lifestyle and oral hygiene level. Oral health habits among the adult population (age over 30 years) was charted in a large population study in 2011. Sixty-seven percent of the dentulous adult population reported brushing their teeth twice a day or more. Only $53 \%$ of men and up to $81 \%$ of women followed the recommended brushing habits. ${ }^{8}$ This steep gender deviation is seen also in the younger population. In the national school healthcare survey in 2017 the mean number of $4^{\text {th }}$ and $5^{\text {th }}$ grade pupils brushing twice a day was $66.4 \%$. Between genders $59.4 \%$ of boys and $73,3 \%$ of girls brushed twice a day. ${ }^{9}$ The management of the increasing burden of diseases demands new solutions. e-Oral health could in the future provide tools to promote self-care, accessibility, oral health equality and service management.

\section{The Finnish healthcare system}

Finland is a sparsely inhabited country with a population of 5.5 million $^{10}$ with a strong public healthcare sector that is responsible for providing affordable health and social services to all citizens. ${ }^{11}$ Private sector and nongovernmental organisations (NGO's) also provide healthcare services, part of which are supported by the public social insurance institution Kansaneläkelaitos (KELA). This National Health Insurance (NHI) also covers prescribed medication and transportation services. ${ }^{12}$ Occupational health services are mainly privately organised and insurancebased funded. The arrangement and funding of the Finnish healthcare system is described in Figure $1 .{ }^{13}$ Comparison of the quality and effectiveness of a country's healthcare system depends on the measures used. Finns are generally satisfied with the healthcare system and the specialised medical care. ${ }^{14}$ On the other hand, there are relatively high out-of-pocket costs and long wait times in the primary healthcare ${ }^{15}$ as well as inequalities in access to healthcare. ${ }^{16}$ Especially in oral

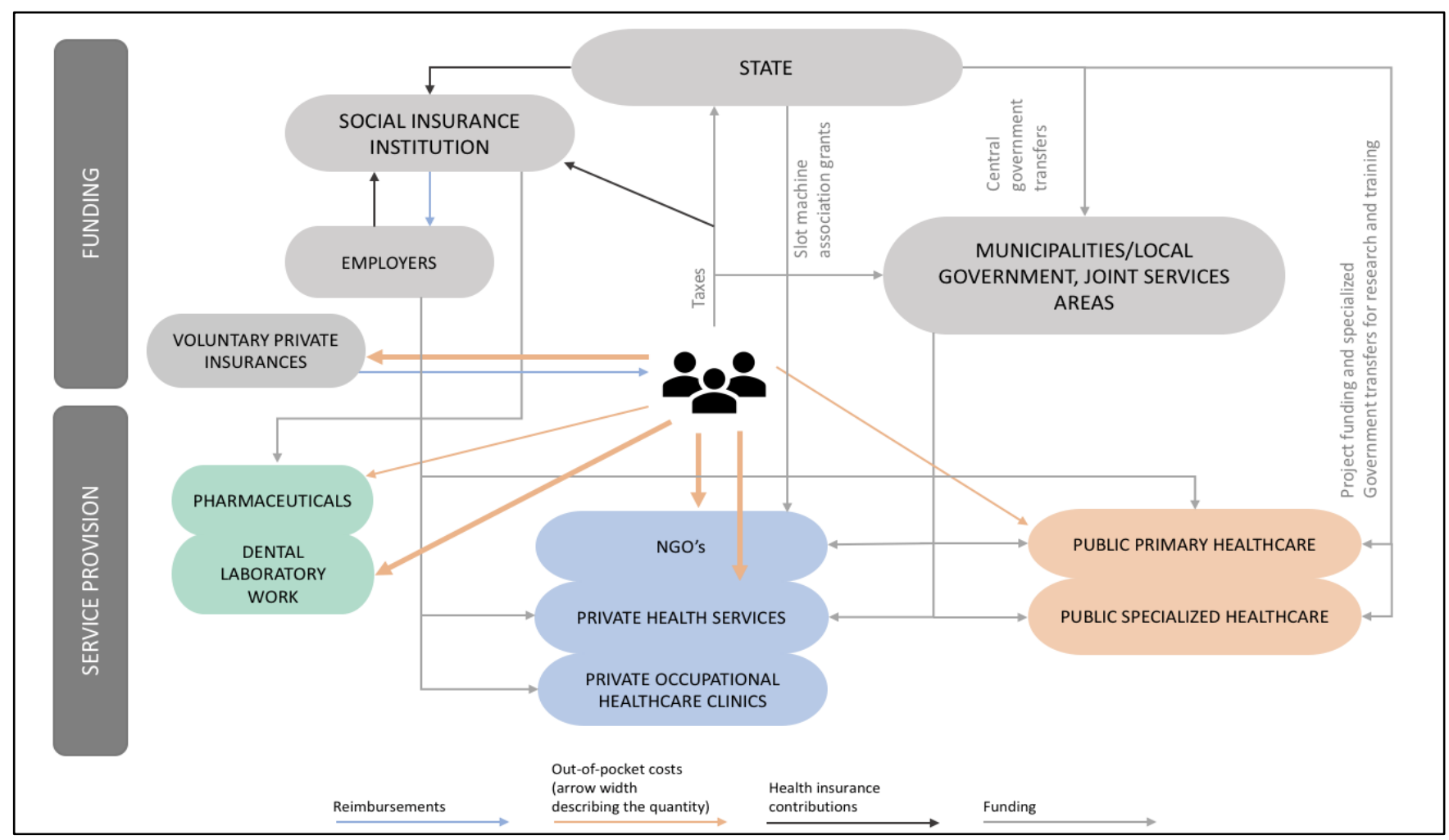

Figure 1. Organisation, funding and supervision of the Finnish healthcare services, modified from ${ }^{13}$. 
health the long waiting lists have led to unmet dental treatment need. ${ }^{17}$

In order to increase equality, accessibility and efficacy, and to simplify the service funding, the Finnish healthcare system is currently going through a social and healthcare reform. In the reform 18 newly formed counties would be responsible for service coordination and the actual service provision would be guided by freedom of choice and market forces among public and private service providers. ${ }^{18}$ Digitalisation and development of ICT systems is tightly connected to the reform strategy. Current development goals are described in the eHealth and eSocial 2020 strategy of the Ministry of Social Affairs and Health. ${ }^{19}$ The strategy themes in all fields of eHealth and eWelfare are:

- Citizens as service users - doing it yourself

- Professionals - smart systems for capable users

- Service system -effective utilisation of limited resources

- Refinement of information and knowledge management - knowledge-based management

- Steering and co-operation in information management - from soloists to harmony

- Infostructure - ensuring a solid foundation

\section{Oral healthcare system}

The four stakeholders that provide oral healthcare services in Finland are the public sector, the private sector, the government and the student healthcare foundation. Primary public oral healthcare serves the vast majority of children and also adults. This is directly organised and funded by cities and municipalities using tax money. Public oral healthcare is free for everyone under 18 years old of age. According to the Finnish healthcare law the city or municipality has to provide a free oral health assessment to the family expecting their first child and a free clinical examination to every child of 1 2, 3-4, 5-6 age, every pupil on their first, fifth and eighth grade and once for every student during their studies. ${ }^{20}$ The public sector is divided into basic level oral healthcare and secondary or specialised level oral healthcare in hospitals. There are 20 healthcare districts responsible for the specialised level health care. These are further combined into five districts led by five university hospitals. ${ }^{12}$ Private services are mainly consumed by the adult population. A relatively marginal but increasing number of people have personal health insurances (voluntary or leisure insurances), ${ }^{12}$ that are mostly for dental trauma cases. The total share of out-of pocket payments in Finnish oral healthcare is $58 \%$. The rest is covered by tax-money $(28 \%)$ and by the general health insurance $(13 \%){ }^{21}$

The Finnish Student Health Service (FSHS) is a foundation responsible for university student healthcare independent from the student's residency. The organisation is funded by out-of-pocket payments $(23 \%)$, the social Insurance Institution of Finland (63\%) and university support funds $(14 \%) .{ }^{22}$ The government organises oral health services for conscripts and prisoners.

In 2017 there were 3,869 practising dentists in Finland a ratio of one dentist to 1,422 people. ${ }^{23}$ There are geographic differences in the service provision and an increasing number of professionals are centred in the big cities. The number of different specialists was 615 in $2018 .^{24}$

\section{The oral health professional education system}

Professionals practicing dentistry and oral health promotion in Finland include dentists and dental specialists, oral hygienists, dental assistants, dental laboratory technicians and special laboratory technicians.

The Doctor of Dental Surgery degree (DDS) in Finland consists of 5 and a half years of academic study and 6 months of practical training in a public health centre. The universities providing basic education are the University of Helsinki, University of Turku (re-established in 2004), University of Oulu and the University of Eastern Finland (re-established in 2010). Specialist training is also coordinated by these universities and additionally by the University of Tampere. The national annual intake for basic dental education is currently 185 students.

After the basic education and a 2-year practical work phase, one can apply for specialised education. There are four 3-year long specialist programs: orthodontics, public oral health, oral diagnostics (radiology, oral pathology, oral microbiology) and clinical dentistry (cariology and endodontology, prosthodontics and oral physiology, periodontology and paediatric dentistry). The specialisation of oral and maxillofacial surgery takes six years.

From the beginning of 2019 the application process for special education will be fully computerised. Additionally, one can apply for a special competence in several areas: dentist trainer, global health, pain management, forensic dentistry, gerodontology, insurance dentistry, dentist-inchief and healthcare information technology (eHealth). The eHealth special competence program has been provided since 2015 for dentists ${ }^{25}$ and is a joint effort of the Finnish Society of Telemedicine and eHealth and the Finnish Dental Association. ${ }^{26}$ At the end of 2018 there were 13 dentists specialised in healthcare information technology (eHealth). ${ }^{27}$

Oral hygienist is a Bachelor's degree (Universities of Applied Sciences) and their scope of practice focuses on preventive oral health care, periodontal anti-infective treatments and oral health education. Laboratory technician is also a Bachelor's degree and they are trained only in Turku University of Applied Sciences. Dental assistants graduate from vocational school and primarily act as chairside assistants with dentists.

\section{Digitalisation in oral health professional education}

The Ministry of Education and Culture supports a strong policy of bringing digitalisation into education from basic to higher level education. Recently a MEDigi project was granted $€ 3.2$ million for harmonising and digitalising medical, dental and veterinary higher education. The project 
aims at building a national platform for standardised medical education and supporting the ICT skills of future medical professionals. $^{28}$ Pioneering the project, the University of Oulu has been providing eHealth theme days for general medicine students since $2016 .^{29}$ Additionally, in dentistry a local co-operation of Kuopio University Hospital Oral Health Teaching Clinic, Savonia University of Applied Sciences City of Kuopio Public Oral Health Care and local private practices are running a Virtual clinic -innovation centre for dental health care (VIRSU)- project. The project will apply modules for teaching and patient education purposes. ${ }^{30}$

\section{Methods}

PubMed and Medline databases were searched in October 2018 including all publication formats where digital oral health or teledentistry tools were applied in the study or were as a focus of the study. Using the terms "(eHealth OR $e$ health OR teledentistry) AND Finland" from all categories. The search produced two hits, both of which were irrelevant (temporomandibular dysfunction studies where traditional statistics were used). Combining the terms "digital AND dentistry AND Finland" yielded no results. Using the terms "digital dentistry AND Finland" 136 papers were identified discussing specific questions related to digital radiology (104), CAD/CAM (3), digital caries light-illumination (DIFOTI) based caries diagnostic (1), oral health data mining (3) and remote data transfer (1). Twenty-four results were irrelevant. Of these results one CAD/CAM systematic review, ${ }^{31}$ three data mining papers, ${ }^{32-34}$ remote data transfer paper $^{35}$ and DIFOTI validation paper have been cited. ${ }^{36}$

Additionally, national reports, current legislation and national databases were searched for current status of national eHealth policies. For the oral health country profile, the citations were chosen from current best evidence of latest large population surveys and compared with WHO country profile data. A minor survey for the three major companies providing CAD/CAM solutions, was also conducted. Only one of the companies provided the information.

\section{Results and Discussion}

\section{National registers and platforms}

As a part of the social and healthcare reform, the government has encouraged a determined strategy for digitalisation of the social and healthcare since 1995. Current efforts are conducted based on eHealth and eSocial 2020 strategy. ${ }^{37}$

Electronic patient records (EPR) that constitute the structured health record and patient data are the first principal components of the Finnish eHealth ecosystem. All healthcare providers, including oral healthcare providers, were obligated to use EPR documentation by 2014 and private providers by $2015 .{ }^{38}$ Compatible EPRs were mandatory for a national e-prescription system that was implemented as a primary and only prescribing channel by $2017 .{ }^{39}$ In 2017 the number of electronic prescriptions was 28,6 million, corresponding to $99 \%$ of all written prescriptions. ${ }^{40}$ The third step for a national eHealth architecture was to bring EPR and prescription data to a national service portal known as "Kanta". It currently contains a centralised national patient health record (PHR), and related services such as electronic prescriptions. Professional-produced data and health records can be accessed by any healthcare service provider with the patient's electronic permission. In "MyKanta", patients are also able to see their own health records online. Oral healthcare providers joined the "Kanta" services in $2016 .{ }^{41}$

Currently there is a stemming production of usergenerated data platforms. During 2016-2018 the ministry of Social Affairs and Health launched the ODA (Omahoito ja Digitaaliset Arvopalvelut/Self-care and Digital Value Services) -project that aims for building a national e-service "OMAOLO" that supports self-care as well as improves service quality, availability and productivity. This "OMAOLO" platform stores user-generated data into "MyKanta Personal Health Record" that is adjacent to "Kanta" services and includes various modules in all fields of healthcare and social services. Cities of Kuopio, Tampere and Turku have produced and added oral healthcare demo modules to the service. The self-educating and service management tools in the service include oral emergency assessment, non-urgent treatment need assessment, and oral health survey for children. Digital tools will be introduced in 2019 to the practical operational frameworks created during the project. ${ }^{42}$ Coordination of the national digital integration will be conducted by the SoteDigi corporation. The aim is to integrate the previous project products (i.e. ODA, UNA, Virtual hospital 2.0) to an integrated national service channel. The service integration is described in Figure 2.

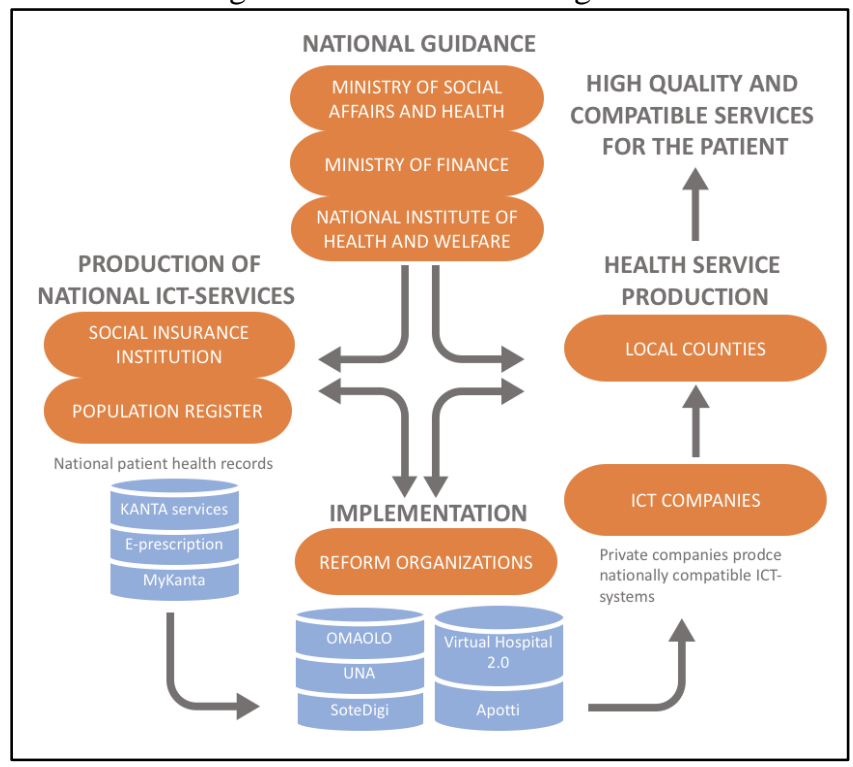

Figure 2. Current strategy of the national ICT ecosystem, modified from Tiedonhallinta rationaalisen lääkehoidon tukena. $^{43}$ 
In addition to the national eHealth platform development, several private companies and FSHS as forerunners, already provide various electronic services. Furthermore, the clinical work has continuously shifted to use new technology solutions.

\section{Dental teleradiology}

Dental radiographs play an important role in the daily clinical diagnostics. Digital intraoral radiography was introduced to clinical practice in Finland in the 1990's. ${ }^{44}$ For efficient teledentistry workflow a high quality imaging system and reliable data storage and transfer systems are required. By 2015 digital x-ray and picture archiving and communication systems (PACS) were available in 21 hospital districts and $99 \%$ of the primary healthcare centres. Traditional films were still used mainly for intraoral dental x-rays in $16 \%$ of the healthcare centres in $2015 .^{37}$

In the 2004 Tsunami in Thailand, the victim identification was supported by forensic dentistry. A Finnish identification team set up a remote consultation portal of dental radiographs that were transferred via mobile network to portable terminal devices at the disaster site. This was one of the first major forensic teledentistry efforts. ${ }^{35}$

\section{Teleconsultation}

Teleconsultation can be considered as a communication between professionals or a patient and a professional. ${ }^{45}$ There is an emerging trend for patients and professionals to search information online. An award-winning teleconsultation portal QA Dental was developed for international professional online consultations. ${ }^{46}$ On the other hand, for patient-professional consultations the FSHS has been a forerunner with general health video appointments in 2018 and upcoming oral health video appointments in $2019 .{ }^{47}$ In the pilot the oral hygienists perform personal hygiene counselling and simple temporomandibular disorder advisory. Dentists will manage online consultations in complex temporomandibular disorders and wisdom tooth related issues.

\section{Digital transillumination and spectral imaging}

Assessment of caries lesions is traditionally performed from intraoral radiographs and through clinical visual-tactile assessment assisted by a fibre optic transillumination (FOTI) white light led-lamp. ${ }^{48}$ DIFOTI is a digital transillumination device that enables capturing the diagnostic illumination image and saving it digitally for follow-up. DIFOTI uses long frequencies of visible light (450 to $700 \mathrm{~nm}$ ). Whereas DIFOTI performed better in initial caries detection, ${ }^{36}$ digital laser fluorescence -based methods NIDIT (Near Infrared Digital Imaging Transillumination) have shown better accuracy in deeper caries lesions. ${ }^{49}$ NIDIT illuminates the alveolar tissue with near infrared $(<700 \mathrm{~nm})$ laser light and the diagnostic images can be digitally saved for patient information and follow-up. The Finnish national guideline of caries diagnostics and management suggests these digital diagnostic methods to support caries diagnostics. ${ }^{50}$ In the
University of Eastern Finland there are currently research projects to develop digital imaging and digital histological staining techniques for oral tissues (teeth, oral mucosa, alveolar bone), using spectral imaging. ${ }^{51,52}$

\section{D planning in digital clinical workflow}

In recent years there has been a strong trend in digitalising the daily clinical workflow especially in restorative dentistry, oral rehabilitation, implantology an orthodontics. The elements that have facilitated the new digital workflow are development in accuracy of the intraoral scanners, low-dose techniques in 3D imaging (mainly cone beam computed tomography, CBCT), low cost 3D-printing and of course development of materials and techniques in computer-aideddesign and computer-aided-manufacturing (CAD/CAM). Digital impressions have proven to be faster and as accurate as conventional impressions in simple fixed prosthodontics, but for full-mouth cases the conventional impressions still overrule. ${ }^{31} \mathrm{CAD} / \mathrm{CAM}$ solutions in crown and bridgework have been in clinical practice for over ten years, but they were mostly restricted to closed data formats which limited usability. Only recently the companies have turned to support open software that allow more versatile use of the open surface geometry data (stereolithography, STL). Integration of surface data models to a 3D-CBCT image has enabled the pre-operative manufacture of CAD/CAM operation splints and guided dental implant design. Also, peri-operative liveguided solutions are emerging. ${ }^{53}$ The involvement to the workflow has mostly been by private clinics and universities. However, an increasing number of public health centres also provide $\mathrm{CAD} / \mathrm{CAM}$ restorations. According to the biggest supplier, there are currently 195 devices in private and 9 in the public sector. In Finland, an estimated 400-500 dentists currently practice in the field of CAD/CAM dentistry. With dental laboratories included into this workflow sharing of large data files through secured cloud services is required. Sharing the digital impressions in seconds to the laboratory saves time, delivery effort and impression materials. It also enables outsourcing the laboratory work nationally or even internationally.

\section{Research and data mining}

EPR and national health registers enable big data mining for research and knowledge-based leadership. For example data mining was used to study the longevity of restorative materials $^{33}$ and permanent molar restorations ${ }^{54}$ from EPR data. Data mining has also proven useful in extracting mean index values for decayed or missing front teeth (DMFT) from EPR free text data. ${ }^{32}$ With data mining it was also found that there is variation in clinical examination accuracy between old and new patients. ${ }^{34}$ Lastly Linden et al $^{55}$ investigated longitudinal examination and visiting patterns in Finnish public oral healthcare using data mining.

The Finnish Innovation Fund (Sitra) has coordinated data lake projects with Helsinki University Hospital, Hospital District of Southwest Finland and Kuopio City for multi- 
source data management. Such oral healthcare data are pooled in Kuopio with social and healthcare data which will enable data mining for broad multivariate research. ${ }^{56}$

\section{Gamifying in oral health}

Gamifying can increase participation and support self-care. ${ }^{57}$ An Oulu University business collaboration has produced Denny, a tooth mobile application that teaches children how to brush their teeth properly and thoroughly during a 2minute period, to support and motivate oral hygiene habits of 5-12 year-old children. In a pilot study of 36 children participants and their parents assessed the usefulness and educative value of the application after a trial period of five weeks. The majority of the sample group found the application useful and informative. Also, the self-reported quality of brushing and interest in oral health had increased. ${ }^{58}$ Gamifying for self-care and oral health education purposes could also be applied in future to the national self-care supporting platforms. ${ }^{41}$

\section{Future aspects}

The previously described national ICT strategies set the foundation to create a national service channel described in Figure 2. Future development will focus on implementing the integration strategy to consolidate the previously built individual ICT areas which lower the organisation boundaries between primary healthcare and specialised healthcare. As a result, the service model should appear to the patient as a constant path without artificial organisationrelated gaps.

The next steps in the integration of clinical workflow could be the fusion of intra- and extra-oral scans (STL -data), CBCT data, and diagnostic transillumination, fluorescence or spectral data. This combination would make traditional status charts old-fashioned. Since the patient should also be increasingly committed through the awareness of their situation, it would be possible to present this visual information in the personal health portal. Like the service path, also the clinical situation updates and workflow should be constant and interrelated. Data mining and artificial intelligence technologies are expected to use this rapidly accumulating data to support diagnostics, decision-making, service management and health policies.

\section{Conclusions}

Dentistry has long been considered as a face-to face interaction with the patient, as the actual treatment can't happen remotely in most cases. However, there is huge potential and unmet need in utilising multi-source data for service management, distant diagnostics and patient followup and information purposes. e-Oral health and teledentistry in Finland is a relatively scattered field, where part of the development lies in national general eHealth strategies without an actual connection to clinical oral health applications. Currently in Finland there is emerging production of e-Oral health applications by private companies, universities and public stakeholders. The rational and guided integration of this big eHealth ecosystem requires strong national level leadership and legislation in order to create a fluent fusion between different applications and stakeholders nationally and internationally. This symbiosis should most importantly serve the patient.

\section{Corresponding author: \\ Anni Palander \\ University of Eastern Finland \\ Institute of Dentistry \\ Kuopio Campus \\ P.O.box 1627 \\ 70211 KUOPIO \\ eMail: anni.riepponen@uef.fi}

Conflict of interest. Anni Palander has worked part time in CSIBIOMED and ODA projects. Arto Holopainen has worked part time for ODA, ISAACUS and MOMEDA teleradiology projects. Tiina Rantamo works part time for VIRSU project.

\section{References}

1. Suominen-Taipale L. Suomalaisten aikuisten suunterveys : Terveys 2000 -tutkimus.

Kansanterveyslaitoksen julkaisuja B: 16/2004.

Available at: http://urn.fi/URN:NBN:fife201204193384 accessed 13 October 2018.

2. Widström E, Järvinen S. Caries prevalence and use of dental services in Finnish children and adolescents in 2009. Oral Health Dent Manag 2011;10(4):185-192. http://oralhealth.ro/volumes/2011/volume4/Paper260.pdf.

3. Kassebaum NJ, Bernabé E, Dahiya M, et al. Global burden of untreated caries: a systematic review and metaregression. J Dent Res 2015;94(5):650-658. DOI: https://doi.org/10.1177/0022034515573272.

4. Kassebaum NJ, Bernabé E, Dahiya M, et al. Global burden of severe periodontitis in 1990-2010: a systematic review and meta-regression. J Dent Res 2014;93(11):1045-1053. DOI: https://doi.org/10.1177/0022034515573272.

5. Kassebaum NJ, Bernabé E, Dahiya M, et al. Global burden of severe tooth loss: a systematic review and meta-analysis. J Dent Res 2014;93(7 Suppl):20S-28S. DPI: https://doi.org/10.1177/0022034514537828.

6. National Cancer Register, data of 2016. Available at: https://syoparekisteri.fi/tilastot/tautitilastot/ accessed 30 November 2018

7. Petersen PE. Oral cancer prevention and control--the approach of the World Health Organization. Oral 
Oncol 2009;45(4-5):454-460. DOI: https://doi.org/10.1016/j.oraloncology.2008.05.023.

8. Koskinen S, Lundqvist A, ja Noora Ristiluoma N. Terveys, toiminta- kyky ja hyvinvointi Suomessa 2011. Terveyden ja hyvinvoinnin laitos (THL), Raportti 68/2012, 1-290. Available at: http://www.julkari.fi/bitstream/handle/10024/90832/U RN_ISBN 978-952-245-769-1.pdf?sequence=1 accessed 13 October 2018.

9. National Institute of Health and Welfare. School Healthcare survey. (2017). Available at: https://sampo.thl.fi/pivot/prod/fi/ktk/ktk4/summary_pe rustulokset?alue $0=87869 \&$ mittarit $0=187209 \&$ mittar it $1=200280 \&$ mittarit $2=200261 \#$ accessed 13 October 2018.

10. Statistics Finland 2018. (2018). Available at: https://www.stat.fi/til/vamuu/2018/10/vamuu_2018_10 2018-11-23 tie 001_en.html accessed 23 November 2018.

11. Health Care Act. (2010). Available at: https://www.finlex.fi/fi/laki/ajantasa/2010/20101326 accessed 23 November 2018.

12. Vuorenkoski L, Mladovsky P, Mossialos E. Finland: Health system review. Health systems in transition. Health Syst Transit 2008;10(4):1-168. Available at: http://www.euro.who.int/ data/assets/pdf_file/0007/8 0692/E91937.pdf accessed 24 November 2018

13. Ministry of Social Affairs and Health. Health care in Finland. (2013). Available at: http://julkaisut.valtioneuvosto.fi/bitstream/handle/1002 4/69930/URN_ISBN_978-952-00-3395-8.pdf accessed 23 November 2018.

14. European Social Survey (ESS). Available at: www.europeansocialsurvey.org accessed 23 November 2018.

15. Eurostat. Statistics on Income and Living Conditions (EU SILC) Available at:

http://www.eui.eu/Research/Library/ResearchGuides/E conomics/Statistics/DataPortal/EU-SILC.aspx accessed 23 November 2018

16. Doorslaer van E, Masseria C. Income-related inequality in the use of medical care in $21 \mathrm{OECD}$ countries. Paris: OECD DELSA/ELSA/WD/HEA (2004).

17. Eurofound 2017: European Quality of Life Survey 2016. Available at:

http://appsso.eurostat.ec.europa.eu/nui/submitViewTab leAction.do accessed 23 November 2018.

18. Couffinhal A, Cylus J, Elovainio R, et al. International expert panel pre- review of health and social care reform in Finland. Reports and Memorandums of the Ministry of Social Affairs and Health 2016:66 Available at: http://julkaisut.valtioneuvosto.fi/bitstream/handle/1002
4/79070/RAP_2016_66.pdf accessed 23 November 2018.

19. Ministry of Social Affairs and Health. Information to support well-being and service renewal. eHealth and eSocial Strategy 2020. Ministry of Social Affairs and Health 2015. Available at:

http://urn.fi/URN:ISBN:978-952-00-3575-4 accessed 23 November 2018.

20. Act of maternity clinic, school and student health care and preventive oral health care for children and youth. (2011). Available at: https://www.finlex.fi/fi/laki/alkup/2011/20110338 accessed 13 October 2018.

21. Seppälä T, Pekurinen M. Sosiaali- ja terveydenhuollon keskeiset rahavirrat. (2014). Available at: https://www.julkari.fi/bitstream/handle/10024/116653/ THL_RAP022_2014verkko.pdf accessed 6 November 2018.

22. Finnish student health service: Our operational basis and funding. Available at:

http://www.yths.fi/yths/yths_n_toiminta_ja_tavoitteet/ yths_n_toiminnan_pohja accessed 16 October 2018.

23. Finnish Dental Association, statistics of dentists in Finland. Available at:

https://www.hammaslaakariliitto.fi/fi/liiton-

toiminta/tutkimukset-ja-

tilastot/tilastot/hammaslaakaritsairaanhoitopiireittain\#.W8HYDi0gkmo accessed 13 October 2018.

24. Finnish Dental Association, statistics of dental specialists in Finland. Available at: https://www.hammaslaakariliitto.fi/node/2224\#.W8HX 4S0gkmo accessed 13 October 2018.

25. Kottonen A. Terveydenhuollon tietotekniikan osaajille riittää työsarkaa. Suom Hammaslaakarilehti 2016;23(3):67.

26. Reponen J. Suomalaisten lääkäreiden ja hammaslääkäreiden terveydenhuollon tietotekniikan erityispätevyys: tavoitteet, sisältö ja ensikokemukset. [Finnish special competence for healthcare information technology to physicians and dentists: aims, contents and initial experiences]. FinJeHeW 2017;9(1):42-45. DOI: https://doi.org/10.23996/fjhw.61134

27. Finnish Dental Association, statistics of dental specialist training in Finland. Available at: https://www.hammaslaakariliitto.fi/fi/opiskelu-jakoulutus/jatkokoulutus/erityispatevyydet accessed 2 November 2018.

28. MEDdigi -Lääketieteen alojen opetuksen digitoiminen ja harmonisointi available at:

https://wiki.eduuni.fi/display/CSCKOOTUKI/Yhteenv eto+erityisavustushankkeista?preview=/41715075/725 20940/MEDigi.pdf accessed 23 November 2018.

29. Jordanova M, Lievens F, Vladzymyrskyy A. Century of Telemedicine: Curatio Sine Distantia et Tempora A 
World Wide Overview - Part II, 2018. Available at: https://www.isfteh.org/files/media/A Century of Tele medicine_Part_II.pdf accessed 23 November 2018.

30. EURA 2014. 2017. Euroopan aluekehitysrahaston (EAKR) rahoittaman hankkeen kuvaus. Työ- ja elinkeinoministeriö. Available at: https://www.eura2014.fi/rrtiepa/projekti.php?projektik oodi=A73199 accessed 23 November 2018.

31. Ahlholm P, Sipilä K, Vallittu P, Jakonen M, Kotiranta U. Digital versus conventional impressions in fixed prosthodontics: a review. J Prosthodont 2018;(1):3541. DOI: $10.1111 /$ jopr.12.

32. Korhonen M, Salo S, Suni J, Larmas M. Computed online determination of life-long mean index values for carious, extracted, and/or filled permanent teeth. Acta Odontol Scand 2007;65(4):214-218. DOI: https://doi.org/10.1080/00016350701321466.

33. Käkilehto T, Salo S, Larmas M. Data mining of clinical oral health documents for analysis of the longevity of different restorative materials in Finland. Int J Med Inform 2009;78(12):e68-74. DOI: http://www.academia.edu/download/30770981/proc20 08louhi.pdf\#page $=34$.

34. Korhonen M, Gundagar M, Suni J, Salo S, Larmas M. A practice-based study of the variation of diagnostics of dental caries in new and old patients of different ages. Caries Res 2009;43(5):339-344. DOI: https://doi.org/10.1159/000231570.

35. Salo S, Salo H, Liisanantti A, Reponen J. Data transmission in dental identification of mass disaster victims. J Forensic Odontostomatol 2007;25(1):17-22. PMID: 17577974.

36. Laitala ML, Piipari L, Sämpi N, et al. Validity of digital imaging of fiber-optic transillumination in caries detection on proximal tooth surfaces. Int J Dent 2017;2017:8289636. DOI: 10.1155/2017/8289636.

37. Hyppönen H, Hämäläinen P, Reponen J. E-health and e-welfare of Finland Check point 2015. National Institute for Health and Welfare report 18/2015. (2015). Available at: http://urn.fi/URN:ISBN:978-952302-563-9 accessed 23 November 2018.

38. Act on the Electronic Processing of Client Data in Healthcare and Social Welfare. (2007). Available at: https://www.finlex.fi/fi/laki/ajantasa/2007/2007015 9\#L7P24 accessed 23 November 2018

39. Act on the Electronic Prescription. (2007) Available at: https://www.finlex.fi/fi/laki/ajantasa/2007/20070061 accessed 23 November 2018.

40. Jormanainen V, Nurmi H, Konttinen R, et al. Suomen lääkemääräysten seurannan ensimmäiset yksitoista kuukautta vuonna 2017. FinJeHeW 2018;10(2-3):200209. DOI: https://doi.org/10.23996/fjhw.68867.

41. National Institute for Health and Welfare. Suun terveydenhuollon potilaskertomusmerkintöjen toiminnalliset määritykset 2016. Available at: https://www.julkari.fi/bitstream/handle/10024/132432/ URN_ISBN_978-952-302-862-3.pdf?sequence=1 accessed 23 November 2018.

42. Palander A, Liukkonen H, Miettinen T, Rajamaa M, Savolainen K. Creating an operational framework for digital multi-disciplinary oral health prevention in children - the ODA Pilot in Kuopio Public Oral Health Care. FinJeHeW 2018;10(4):396-404. DOI: https://doi.org/10.23996/fjhw.74578.

43. Tiedonhallinta rationaalisen lääkehoidon tukena. Available at: https://stm.fi/rationaalinenlaakehoito/tiedonhallinta accessed 30 November 2018.

44. Gröndahl HG, Wenzel A, Borg E, Tammisalo E. An image plate system for digital intra-oral radiography. Dent Update 1996;23(8):334-337. PMID:9452625

45. Deldar K, Bahaadinbeigy K, Seyed Mahmood Tara S. Teleconsultation and clinical decision making: a systematic review Acta Inform Med 2016; 24(4):286292. DOI: 10.5455/aim.2016.24.286-292.

46. QA Dental portal website. Available at : https://terveydenhuolto.com/QAdental, accessed 8 April 2019.

47. Finnish student health service: remote consultation and remote physiotherapy pilots in five districts. Available at:

https://www.yths.fi/uutiset/1036/etavastaanottoa_ja_et afysioterapiaa_kokeillaan_viidella_paikkakunnalla accessed 8 April 2019.

48. Twetman S, Axelsson S, Dahlén G, et al. Adjunct methods for caries detection: A systematic review of literature. Acta Odontol Scand 2013;71(3-4):388-397. DOI: 10.3109/00016357.2012.690448.

49. Gimenez T1, Braga MM, Raggio DP, et al. Fluorescence-based methods for detecting caries lesions: systematic review, meta-analysis and sources of heterogeneity. PLoS One 2013;8(4):e60421. DOI: 10.1371/journal.pone.0060421.

50. National "Käypä hoito" guidelines: Caries (2014). Available

at: http://www.kaypahoito.fi/web/kh/suositukset/suosit us?id=nak06749\&suositusid=hoi50078 accessed 29

November 2018.

51. Fält P, Hyttinen J, Fauch L, et al. Spectral Image Enhancement for the Visualization of Dental Lesions. In: Mansouri A, El Moataz A, Nouboud F, Mammass D. (eds) Image and Signal Processing. ICISP 2018. Lecture Notes in Computer Science, vol 10884. Springer, Cham

52. Fauch L, Palander A, Koistinen A, Kullaa A, Keinänen M. Narrowband-autofluorescence imaging for bone analysis. Biomed Opt Express 2019;10(5):2367-2382. DOI: https://doi.org/10.1364/BOE.10.002367

53. Nobel Biocare: X-guide Computer-guided dental implant surgery. Available at: 
https://www.nobelbiocare.com/fi/en/home/productsand-solutions/treatment-concepts/guided-surgery/xguide.html?redirect=true accessed 8 April 2019.

54. Vähänikkilä H, Käkilehto T, Pihlaja J, et al. A databased study on survival of permanent molar restorations in adolescents. Acta Odontol Scand 2014;72(5):380-385. DOI: 10.3109/00016357.2013.844270.

55. Linden J, Josefsson K, Widström E. Frequency of visits and examinations in the Public Dental Service in Finland - a retrospective analysis, 2001-2013. BMC Oral Health 2017;28;17(1):138. DOI: 10.1186/s12903017-0436-8.

56. Finnish Innovation Fund (Sitra). Isaacus preproduction project, available at: https://www.sitra.fi/en/projects/isaacus-preproduction-projects/ accessed 30 November 2018.

57. Haaranen A, Rissanen T, Laatikainen T, Kauhanen J. Digital and video games in health promotion: Systematic review of games and health behavior FinJeHeW 2014;6(4):153-163, 2014. Available at: https://journal.fi/finjehew/article/view/48209 accessed 30 November 2018.

58. Toratti A, Rasmus K, Laitala M, Pesonen P, Anttonen V. The effect of a mobile application for children's oral health behaviour - a pilot study. Abstracts of the 26th Congress of the International Association of Paediatric Dentistry, 4-7 October 2017, Santiago, Chile. Int J Paediatr Dent 2017;27(S2):36-140. DOI: https://doi.org/10.1111/ipd.12332. 